DOI: https://doi.org/10.24144/2409-6857.2018.1(51).91-94

УДК: 330.59 : 352 : 331.2 (477)

Переверзсва А.В.

\title{
ОЦІНКА РІВНЯ ЖИТТЯ В ОБ'ЄДНАНИХ ТЕРИТОРІАЛЬНИХ ГРОМАДАХ: НАЦІОНАЛЬНІ ТА МІЖНАРОДНІ СТАНДАРТИ
}

\begin{abstract}
У статті досліджено поняття рівня життя населення. Виокремлено рівні життя населення, а саме: достаток, нормальний рівень життя і бідність. Здійснено порівняльний аналіз рівня заробітної плати 8 об'єднаних територіальних громадах та критеріальних значень щзодо мінімального рівня доходу, які запропоновані міжнародними інституціями, такими як ООН та Світовий банк. Визначено, щзо рівень життя населення в громадах не відповідає міжнародним стандартам, адже населення 72 \% громад має рівень доходів, який не відповідає мінімальним критеріальним значенням, які використовують ООН та Світовий банк. Обтрунтовано, щзо рівень заробітної плати у окремих об'єднаних територіальних громадах не відповідає начіональному критерію стандартів рівня життя населення.
\end{abstract}

Ключові слова: рівень життя, об'єднані територіальні громади, міжнародні стандарти, поріг бідності, мінімальна заробітна плата, критерії.

Постановка проблеми. Загострення кризових явищ у світовій та національній економіках безпосередньо віддзеркалюється на рівні життя населення. Значна диференціація умов i зниження добробуту, нерівномірність розподілу доходів, низькі соціальні стандарти не відповідають критеріальним значенням, визначеним на міжнародному рівні. Внаслідок обмеження фінансових засобів більшість населення не має можливості задовольняти мінімальні потреби, не говорячи вже про максимальну реалізацію людського потенціалу. Держава не в змозі повною мірою забезпечити повноцінний розвиток людських ресурсів, тому ступінь реалізації прагнень або бажань індивіда чи групи людей у товарах та послугах, тобто зростання рівня життя, стає провідним завданням для об'єднаних територіальних громад, які формуються в національній економіці в умовах активізації процесів децентралізації. У зв'язку із цим питання щодо оцінки рівня життя населення в об'єднаних територіальних громадах та його відповідності національним стандартам та міжнародним критеріям $є$ актуальним 3 точки зору пошуку ефективних методів підвищення добробуту населення людей.

Аналіз останніх досліджень і публікацій. Значний науковий інтерес до поняття «рівень життя» проявляється 3 давнини. Вперше поняття «рівень життя» розглянув представник класичної школи У. Петті, який пов'язував його із трудовою діяльністю. Дохід працівника, на

(C) Переверзєва Анна Василівна, к.е.н., доцент кафедри міжнародної економіки, природних ресурсів i економічної теорії, Запорізький національний університет, м. Запоріжжя, тел.: 0975718316, email: pereverzeva@ukr.net думку вченого, мав забезпечити йому життя на рівні задоволення мінімальних потреб існування $[1$, c. 70-71]. Головний представник школи фізіократів Ф. Кене вперше розробив економічну концепцію відтворення та розподілу суспільного продукту, що $\epsilon$ джерелом ресурсів для задоволення потреб основних верств населення [2, c. 356].

Різні аспекти рівня життя населення досліджувалися українські та зарубіжні вчені, а саме: O. I. Амоша, А. Базилюк, Д. Богиня, I. Борей, О. М. Краснікова, Е. Лібанова, В. Майєр, О. Мандибура, С.I. Пирожков, Л. М. Черенько, В.I. Шишкін та інші.

Разом 3 тим слід зазначити, що питання оцінки рівня життя в об'єднаних територіальних громадах та співставлення національних та міжнародних стандартів потребує додаткового дослідження i обгрунтування, a національні стандарти вимагають адаптації до реалій сучасної економіки та міжнародних критеріїв.

Формулювання цілей статті. Метою статті $\epsilon$ оцінка рівня життя в об'єднаних територіальних громадах за національними й міжнародними стандартами та надання рекомендацій щодо його підвищення.

Опис основного матеріалу дослідження. Активізація процесів децентралізації в національній економіці сприяє формуванню територіальних утворень - об'єднаних територіальних громад, які володіють певним ресурсним потенціалом. Успішність діяльності громад залежить від людських ресурсів, які $є$ головною рушійною силою їх розвитку. Для того, щоб громада була успішною і самодостатньою, вкрай необхідно забезпечити належний рівень життя населення, яке буде здатне не лише задовольнити мінімальні 
потреби, але й максимально реалізувати свій потенціал.

У зв'язку із цим необхідно визначити поняття «рівня життя». В науковій літературі це питання $\epsilon$ дискусійним, оскільки одні вчені вважають, що рівень життя потрібно досліджувати виключно в межах сфери споживання, і тому це поняття має виражати лише ступінь забезпеченості людей відповідними життєвими благами (споживчими товарами та послугами), а інші зазначають, що дефініція «рівень життя» свідчить про ступінь розвитку i повноту задоволення життєвих потреб, пов'язаних із життєдіяльністю людини, які мають місце в суспільстві і окреслюються поняттям «добробут» [3, с. 15].

У загальному розумінні рівень життя - це характеристика економічного добробуту населення, що вимірюється як реальний дохід на душу населення та кількістю населення, яка проживає за межею бідності.

Рівень життя у вузькому розумінні - це характеристика рівнів споживання населення і ступеня задоволення його потреб (вимірювання доходів, витрат і споживання благ та послуг). Під рівнем життя в широкому розумінні розглядають рівень людського розвитку (стан здоров'я, можливості населення для задоволення своїх потреб) та умови життєдіяльності населення (стан навколишнього середовища та безпека населення).

В економічній літературі поняття «рівень життя» розглядається з точки зору двох підходів: рівня задоволення потреб та рівня доходу. Представники першого підходу $[4$, с. $135 ; 5$, с. 5$]$ розглядають рівень життя через масштаби реалізації потреб населення, що виступають базовою одиницею виміру, а також характеризує досягнутий на визначений проміжок часу в суспільстві ступінь задоволення різноманітних потреб населення (фізичні, соціальні, інтелектуальні, духовні, політичні), включаючи реальні економічні джерела та соціально-правові гарантії забезпечення умов життєдіяльності населення. 3 точки зору другого підходу [5, с. 21] поняття рівня життя розглядається через матеріальне забезпечення людей (заробітна плата, джерела добробуту, забезпечення житлом, роботою, соціальні гарантії тощо). Вищезазначені підходи у зарубіжній практиці сформувалися як дві концепції «рівня життя» [6, с. 16-17]:

- перша концепція розглядає рівень життя як матеріальне становище населення (у розумінні наявності необхідних матеріальних благ у вигляді доходу для підтримання основних життєвих потреб, забезпеченості певним рухомим та нерухомим майном тощо). Основну увагу зосереджено на визначенні раціональних норм споживання та відповідності реального споживання цим нормам, рівня купівельної спроможності та доходів, обгрунтуванню їх диференціації в суспільстві, встановленню соціальних стандартів;

- друга концепція (якості життя) базується на визнанні необхідності задоволення потреб людини не тільки в матеріальних благах, а й в умовах для розвитку й життєдіяльності, та означає частковий перехід від макроекономічного до мікроекономічного розуміння.

Кількісна оцінка рівня життя населення передбачає комплексний аналіз системи показників, які певною мірою характеризують матеріальний добробут, соціальне середовище, умови проживання та інші важливі аспекти людської життєдіяльності. Важливою її характеристикою $€$ також те, що на іiі основі можна визначати узагальнений результат діяльності економіки за певний період, оцінити ефективність як державної, так і регіональної політики.

У міжнародній статистиці використовуються 12 груп показників рівня життя: народжуваність, смертність та інші демографічні показники; санітарно-гігієнічні умови життя; споживання продовольчих товарів; житлові умови; освіта й культура; умови праці та зайнятість; доходи й витрати населення; вартість життя і споживчі ціни; транспортні засоби; організація відпочинку; забезпечення; свобода людини.

У національній економіці для оцінки й аналізу життєвого рівня населення використовують різні показники, такі як обсяг валового внутрішнього продукту, національного і реального доходу на душу населення, обсяг послуг на душу населення, середній рівень заробітної плати, забезпеченість житлом та інші. Окрім того, життєвий рівень населення країни характеризують показники середньої тривалості життя, народжуваності і смертності населення.

Згідно 3 нормативами чи стандартами виокремлюють такі рівні життя населення [7]:

- достаток - це рівень життя, який дає змогу користуватись усіма благами, що забезпечують всебічний розвиток людини;

- нормальний рівень життя - забезпечує раціональне споживання відповідно до науково обгрунтованих норм та нормативів, що дає можливість людині відновлювати свій фізичний та інтелектуальний потенціал;

-бідність - це рівень життя, за якого споживання перебуває на рівні збереження працездатності як нижньої межі відтворення життевих сил.

На світовому рівні використовують власну систему критеріїв, яка дозволяє визначити рівень життя, i на основі цього здійснити класифікацію країн. В міжнародній практиці використовують 
певні критеріальні значення, які відповідають мінімальному рівню доходу. Наприклад, за стандартами ООН поріг бідності складає 5 доларів на день на одну особу, за Світовим банком - цей показник становить 4 долари, Тобто, якщо людина витрачає на проживання та продукти харчування менше, то вона живе за порогом бідності. В національній економіці встановлені мінімальні стандарти рівня життя населення, серед яких головними $є$ мінімальна заробітна плата, прожитковий мінімум та інші. Прожитковий мінімум включає витрати на продукти харчування, транспортні витрати, оплата побутових та комунальних послуг та інше, крім витрат на медичне обслуговування та освіту. Тобто національні стандарти дозволяють задовольняти лише матеріальні потреби. Якщо рівень доходів не відповідає мінімально визначеним критеріям, то це свідчить про критичний стан, який визначається неможливістю задовольнити першочергові потреби, не говорячи вже про повну реалізацію людського потенціалу.

На нашу думку, для оцінки рівня життя населення об'єднаних територіальних громад можна використати рівень оплати праці, який дозволяє визначити наскільки життя членів громади відповідає мінімальним національним i міжнародним стандартам.

Для того, щоб визначити чи $є$ достатнім рівень оплати праці в об'єднаних територіальних громадах для задоволення потреб та реалізації людського потенціалу, необхідно здійснити порівняльний аналіз рівня заробітної плати в громадах та критеріальних значень щодо мінімального рівня доходу. Визначених міжнародними інституціями.

Таблиця 1

Критеріальні значення мінімального рівня доходу за визначенням міжнародних інституцій *

\begin{tabular}{|l|l|l|l|}
\hline Міжнародні організації & Критеріальні значення & Україна 1дол. =26 грн. (2016 р.) & На місяць (30 днів) \\
\hline ООН & $5 \$$ на день/особу & 130 грн. на день/особу & 3900 грн./особу \\
\hline Світовий банк & $4 \$$ на день/особу & 104 грн. на день/особу & 3120 грн/особу \\
\hline
\end{tabular}

* Складено автором на основі [8-9]

Найбільш розповсюдженими є критерії, запропоновані ООН, згідно 3 якими значення мінімального рівня доходу складає 5 дол. на день/особу (130 грн. на день/особу) та Світового банку - 4 дол. на день/особу (104 грн на день/особу). У розрізі національної економіки в розрахунку на місяць за критерієм ООН - це
3900 грн/особу, а за Світовим банком 3120 грн/особу (табл. 1). Для визначення рівня доходу i його відповідності міжнародним критеріям, проаналізуємо рівень заробітної плати в об'єднаних територіальних громадах та порівняємо його $з$ стандартами, наданими ООН та Світовим банком (рис. 1).

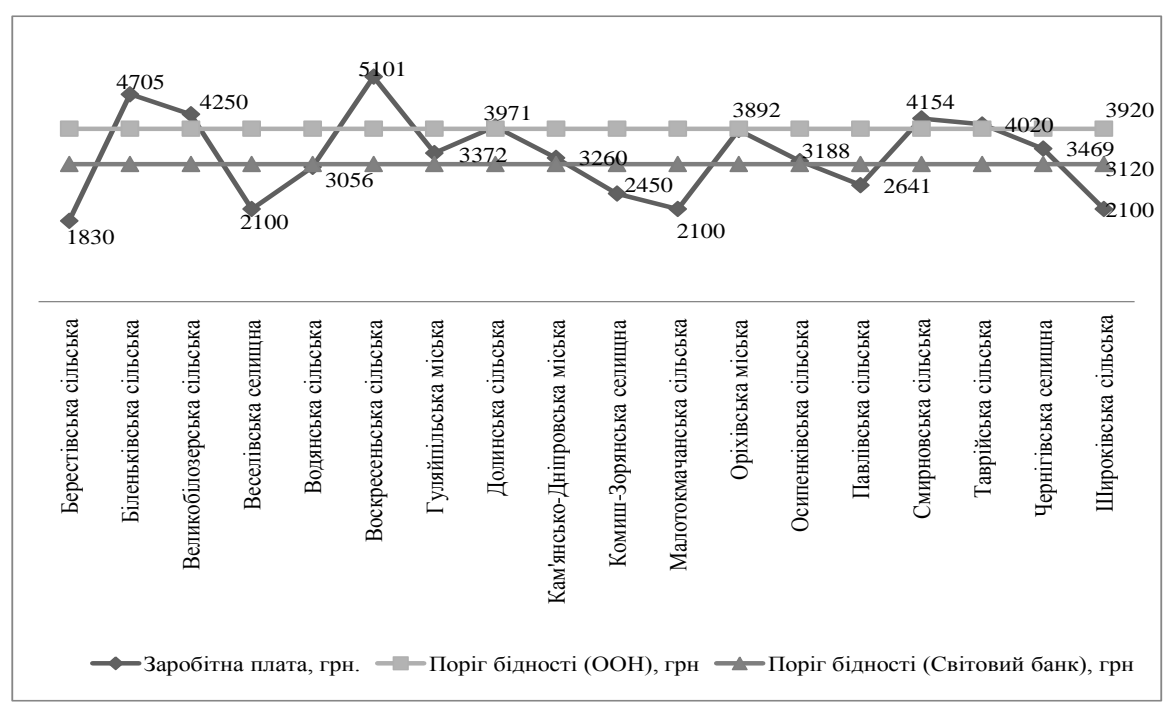

Рис. 1. Порівняльний аналіз рівня оплати праці в об’сднаних територіальних громадах 3 критеріальними значеннями міжнародних інституцій, \% *

* Розроблено автором 
Нами проаналізовано рівень заробітної плати у 18 об'єднаних територіальних громадах Запорізької області.

Аналіз рис.1 свідчить про те, що 6 громад (33 \%) мають рівень заробітної плати, нижчий за критерій Світового банку - 4 дол. на день/особу і 7 громад (39 \%) - 5 дол. на день/особу. На основі проведеного аналізу, слід підсумувати, що $72 \%$ громад мають рівень доходів, нижчий за критеріальні значення, визначені міжнародним інституціями. Це свідчить про відсутність можливостей для задоволення потреб людей i повної реалізації людського потенціалу.

Якщо говорити про національні мінімальні стандарти, то їх розмір $\epsilon$ неприйнятним для забезпечення нормальної життєдіяльності людини: мінімальна заробітна плата в Україні у 2016 р. становила 1600 грн., а прожитковий мінімум - 1550 грн. (2016 р.).

Станом на 01.01.2018 р. рівень мінімальної заробітної плати в України складає 3700 грн. Зазначимо, що рівень заробітної плати у окремих об'єднаних територіальних громадах не відповідає національному критерію стандартів рівня життя населення.

\section{ПЕРЕЛІК ВИКОРИСТАНИХ ДЖЕРЕЛ}

1. Петти У. Экономические и статистические работы. - М.: Соцекгиз, 1940. - С. 70-71.

2. Кенэ Ф. Избранные экономические произведения. - М.: Соцэкгиз, 1960. - С. 356

3. Мандибура В.О. Рівень життя населення та механізми його регулювання : Автореф. дис... д-ра екон. наук: 08.09.01 / В.О. Мандибура; НАН України. Ін-т економіки. - К., 1999. - 36 с.

4. Гукалова І.В. Якість життя населення України: суспільно-географічна концептуалізація [Текст]: монографія / І. В. Гукалова. - Інститут географії НАН України. - К.: 2009. - 347 с.

5. Кремлев Н.Д. Проблемы оценки уровня жизни населения / Н.Д. Кремлев // Вопросы статистики. - 2000. № 8. - C. $18-23$.

6. Рівень життя населення України / НАН України. Ін-т демографії та соц. дослідж., Держ. ком. статистики України; За ред. Л. М. Черенько. - К.: ТОВ “Видавництво “Консультант”, 2006. - 428 с.

7. Майер Е.Ф. и др. Планирование социального развития и повышение уровня жизни народа. - М.: МГУ, 1998. - $271 \mathrm{c}$.

8. Стандарт ООН [Електронний ресурс]. - Режим доступу: www.un.org/ru.

9. Сайт Світового банку [Електронний ресурс]. - Режим доступу: www.worldbank.org.

\section{REFERENCES}

1. Petti, U. (1940) Ekonomicheskie i statisticheskie raboty [Economic and statistical papers], M.: Sotsekhiz [in Russian].

2. Kene, F. (1960) Izbrannyie ekonomicheskie proizvedeniya [Selected Economic Papers], M.: Sotsekhiz [in Russian].

3. Mandybura, V.O. (1999) Riven zhyttia naselennia ta mekhanizmy yoho rehuliuvannia [Living standards and mechanisms of its regulation]. Extended abstract of Doctor's thesis. In-t ekonomiky, Kyiv [in Ukrainian].

4. Hukalova, I.V. (2009) Yakist zhyttia naselennia Ukrainy: suspilno-heohrafichna kontseptualizatsiia [The quality of life in Ukraine: social and geographical conceptualization]. In-t heografii Ukrainy, Kyiv [in Ukrainian].

5. Kremlev, N.D. (2000) Problemy otsenki urovnia zhyzni naselenia [The problems of living standards assessment]. Voprosy statistiki, 8, 18-23 [in Russian].

6. Cherenko, L.M. (Eds.) (2006) Riven zhyttia naselennia Ukrainy [Living standard of Ukraine]. K.: TOV «Vydavnytstvo «Konsultant» [in Ukrainian].

7. Mayer, E.F. (1998) Planirovanie sotsialnogo razvitiya i povyishenie urovnya zhizni naroda [Planning for social development and improving people's living standards]. M.: MHU [in Russian].

8. Standart OON [The UN Standard]. un.org/ru. Retrieved from: www.un.org/ru [in Russian].

9. Sait Svitovoho banku [Site of the World bank]. worldbank.org. Retrieved from: www.worldbank.org [in English].

Одержано 09.02.2018 p. 